\title{
EFFECT OF PYROLYSIS TEMPERATURE ON DESULFURIZATION PERFORMANCE OF HIGH ORGANIC SULFUR LOW RANK COAL
}

\author{
W. Xia ${ }^{1 \#, ~ W . ~ H e}{ }^{1}$, J. Sokolović \\ ${ }^{1}$ China University of Mining and Technology, \\ School of Chemical Engineering and Technology, Jiangsu, China \\ 2University in Belgrade, Technical Faculty, Bor, Serbia
}

Received: November 2, 2020; Accepted: March 30, 2021

\begin{abstract}
The sulfur in coal not only influences the coke quality but also pollutes the environment during the combustion. The desulfurization of high organic sulfur coal is a key issue in coal cleaning science. As the pyrolysis has been used in low rank coal conversion to obtain gas/liquid products and coal char, the desulfurization effects of pyrolysis on the low rank coal with high organic sulfur requires further studies. This study investigated the desulfurization performance of high organic sulfur low rank coal by the pyrolysis and the changes in the coal calorific value and sulfur forms during the pyrolysis. The XPS was applied to analyze the changing regulation of sulfur that forms on coal surface. The results indicated certain amount of FeS was newly created during the pyrolysis and high amounts of sulfate sulfur was transferred to pyrite sulfur and formed more FeS 2 when compared to the distribution of raw coal. The total sulfur content of coal was reduced from $2.32 \%$ for raw coal to $1.68 \%$ for $700{ }^{\circ} \mathrm{C}$ pyrolysis coal and then the pyrolysis temperature had little effect on the sulfur content. The net calorific value (at constant volume and air-dry basis) was increased from $17.38 \mathrm{~kJ}$ for raw coal to $24.35 \mathrm{~kJ}$ for $700{ }^{\circ} \mathrm{C}$ pyrolysis coal. The pyrolysis temperature of $700{ }^{\circ} \mathrm{C}$ may be the best pyrolysis temperature for both low sulfur content and high calorific value.
\end{abstract}

Key words: Coal desulfurization; Pyrolysis; XPS; Calorific value; Sulphur content.

\section{Introduction}

The desulphurization of coal is important for the environmental protection during the burning of coal for power generation [1 - 4]. As is known, the reserves of low rank coal are abundant around the world and majority of low rank coal is used for the power generation and gas/liquid chemical raw materials. Common coal desulfurization approaches are divided into three major types, i.e., desulfurization before utilization, sulphur-fixing during the burning, and desulfurization of flue gas $[3,5,6]$. Among these approaches, the desulphurization of coal before utilization is considered as more economic and effective [7].

Generally, gravity-based physical and flotation are used for coal desulfurization and deashing in coal preparation plants [8 - 11]. However, organic sulfur cannot be removed from coal because organic sulfur is usually bonded with coal organic materials. In laboratorial studies, organic sulfur can be partly removed from coal organic materials through chemical treatments, such as oxidation and leaching, as well as bio-desulfurization using bacterial [12 - 16]. However, these chemical- or bio-treatments cannot be well applied in industry.

In the past decades, a better utilization of low rank coal has reached an agreement that the pyrolysis treatment under lower temperature could transfer low rank coal into gaseous/liquidus chemical raw materials and coal char [17]. While gas/liquid chemical raw materials are used in chemical engineering, coal char is primarily forwarded to coal-based power generation plants for burning. The coal properties can be significantly changed during the pyrolysis. Among these changes, the sulfur forms in coal are also changed and requires in-depth studies [18 - 20]. The decomposition of organic sulfur begins with the formation of -SH radicals [21], which interact with some of the substances in the coal to produce $\mathrm{H}_{2} \mathrm{~S}, \mathrm{COS}, \mathrm{CS}_{2}$, etc. In general, the decomposition temperature of aliphatic and aromatic thiols is about $200-300{ }^{\circ} \mathrm{C}$, while the decomposition of fatty sulfur compounds occurs at $350-500{ }^{\circ} \mathrm{C}$, and the 
decomposition temperature of aromatic sulfides are in the range of $700-800{ }^{\circ} \mathrm{C}$. The decomposition temperature of thiophene compounds is usually higher than $900{ }^{\circ} \mathrm{C}[22,23]$. However, there is a gap in the investigation of the influence of pyrolysis on the changes of coal calorific value.

This paper aimed to study the feasibility of desulfurization of low rank coal with large organic sulfur fraction by the pyrolysis and the changes in the coal calorific value and sulfur forms during the pyrolysis. The XPS was applied to analyze the changing regulation of sulfur forms of coal surface to explain what reactions happened during the pyrolysis.

\section{Experimental material and procedure}

\subsection{Coal material}

The coal sample was taken from Xinglinhaote of Inner Mongolia, China. Coal particles were firstly ground and then screened to $0.074 \mathrm{~mm}$ for subsequent use. The industrial analysis and sulfur existing form of this coal material were indicated in Table 1 [24]. The total content of sulfur on low rank coal was $2.32 \%$ and among it, the organic sulfur took up for $2.00 \%$, suggesting that the organic sulfur was dominant in the total sulfur distribution.

Table 1 Industrial analysis and sulfur existing form of used coal samples [24]

\begin{tabular}{|c|c|}
\hline Proximate analysis $/ \%$ & $\begin{array}{l}\text { Sulfur forms analysis } \\
\qquad 1 \%\end{array}$ \\
\hline Vdaf FCdaf $S(t, d)$ & $S(p, d) \quad S(s, d) \quad S(o, d)$ \\
\hline $14.79 \quad 13.21 \quad 65.1934 .81$ & $0.25 \quad 2.00$ \\
\hline \multicolumn{2}{|c|}{$\begin{array}{l}\text { Mad is the moisture of air-dry basis. Ad is the ash of the dry } \\
\text { basis. FCdaf and Vdaf: fixed carbon and volatile matter } \\
\text { contents of the dry-ash free basis. } S(t, d), S(p, d), S(s, d) \text {, and } \\
S(0, d) \text { are the total sulfur, pyrite sulfur, sulfate sulfur, and } \\
\text { organic sulfur contents based a dry basis, respectively. }\end{array}$} \\
\hline
\end{tabular}

\subsection{Linguistic variable}

The pyrolysis treatment of low rank coal (about $24 \mathrm{~g}$ per treatment) was conducted in the tube furnace with purge gas of $\mathrm{N}_{2}$ for the residence time of 1 hour. The experimental parameters were set as follows: the pyrolysis temperature was fixed at 400, 500,600, 700 , and $800{ }^{\circ} \mathrm{C}$. The desulfurization performance was evaluated using the sulfur content and yield of the coal char.
The industrial analysis of low rank coal after pyrolysis of different temperatures is shown in Table 2. The moisture, fixed carbon, and volatile matter content of pyrolytic char decreased when heating treatment temperature increased while the ash content increased.

Table 2 Proximate analysis of low rank coal after pyrolysis of different temperatures

\begin{tabular}{lrrrr}
\hline Coal samples & $M_{a d} / \%$ & $A_{d} / \%$ & $V_{\text {daf }} / \%$ & $F_{\text {daf }} / \%$ \\
\hline $400{ }^{\circ} \mathrm{C}$ pyrolysis coal char & 12.66 & 17.95 & 30.09 & 69.91 \\
$500{ }^{\circ} \mathrm{C}$ pyrolysis coal char & 11.54 & 19.99 & 19.16 & 80.84 \\
$600{ }^{\circ} \mathrm{C}$ pyrolysis coal char & 9.15 & 21.57 & 12.03 & 87.97 \\
$700{ }^{\circ} \mathrm{C}$ pyrolysis coal char & 6.79 & 22.82 & 5.61 & 94.39 \\
$800^{\circ} \mathrm{C}$ pyrolysis coal char & 5.47 & 23.09 & 3.48 & 96.52 \\
\hline
\end{tabular}

2.3. Sulfur content and calorific value measurements

Raw coal sample and pyrolytic coal char were then conducted to measure the sulfur content and calorific value employing the automatic coulomb sulfur analyzer and automatic calorimeter. Repeated tests were carried out to calculate the average sulfur content of samples to ensure the accuracy.

\subsection{XPS tests}

To obtain an insight observation of the sulfur existing forms variation on low rank coal surface before and after heating treatment, the XPS testing was used to quantify the chemical status. The XPS testing of raw low rank coal and pyrolysis coal were conducted under the ultra-high vacuum (UHV) system at room temperature by the surface analyzer (ESCALAB $250 \mathrm{Xi}$, USA). The raw data results were processed applying the software of XPS Peak. The binding energy should be corrected by fixing $-\mathrm{CH}_{2}-\mathrm{CH}_{2}$ - bonding energy position at $284.8 \mathrm{eV}$. The S2p peaks of raw coal and pyrolysis coal were analyzed to see what have happened to the coal when pyrolyzing.

\section{Results and discussion}

\subsection{Effect of pyrolysis temperature on desulfurization performance}

Figure 1 illustrates both the sulfur content and coal char yield reduced with higher heating temperature. The sulfur content of raw coal was $2.32 \%$, however, it was 
reduced to about $1.68 \%$ for the $700{ }^{\circ} \mathrm{C}$ pyrolysis coal char. The sulfur content of $800{ }^{\circ} \mathrm{C}$ pyrolysis coal char was similar to that of $700{ }^{\circ} \mathrm{C}$ pyrolysis coal char indicating the pyrolysis temperature over $700{ }^{\circ} \mathrm{C}$ had no significant effects on the coal char sulfur content. Therefore, the pyrolysis temperature of $700{ }^{\circ} \mathrm{C}$ was considered as an optimized temperature to release the sulfur of the low rank coal.

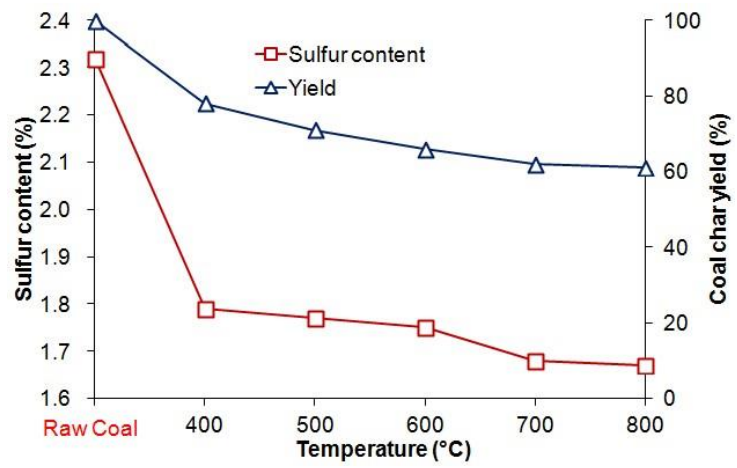

Figure 1 Changes in sulfur content and yield of coal with pyrolysis temperature

Chemical titration analysis was performed to investigate the sulfur existing forms of coal surfaces before and after pyrolysis treatment of $700{ }^{\circ} \mathrm{C}$. Table 3 indicates that the organic sulfur content of coal decreased from $2.00 \%$ to $1.28 \%$ after the pyrolysis treatment under the $700{ }^{\circ} \mathrm{C}$. The sulfate sulfur fraction of coal reduced from $0.25 \%$ to $0.05 \%$, while the pyrite sulfur content of coal increased from $0.07 \%$ to $0.35 \%$ due to the migration of the sulfate sulfur to the pyrite sulfur among pyrolysis treatment [25 - 27]. The decomposition of organic sulfur occurred during the pyrolysis [22, 23], and the sulfur-containing gaseous/liquidus generated.

Table 3 Sulfur existing forms of raw coal and $700{ }^{\circ} \mathrm{C}$ pyrolysis-derived coal char

\begin{tabular}{lrlll}
\hline Sample name & $S(t, d)$ & $S(p, d)$ & $S(s, d)$ & $S(o, d)$ \\
\hline Raw coal & 2.32 & 0.07 & 0.25 & 2.00 \\
$700{ }^{\circ} \mathrm{C}$ pyrolysis coal char & 1.68 & 0.35 & 0.05 & 1.28 \\
\hline
\end{tabular}

For the sake of revealing the changing mechanism of sulfur existing forms on the coal surface clearly, XPS was employed to confirm the sulfur existing forms of both raw coal and $700{ }^{\circ} \mathrm{C}$ pyrolysis-derived coal char. For the S2p peak fitting, the peaks near $161.2 \pm 0.2$, $162.5 \pm 0.3,163.5 \pm 0.3,165.2 \pm 0.2,167.0 \pm 0.2,168.9$,
170.5, and $172.2 \mathrm{eV}$ bound to ferrous sulfide (FeS), ferrous disulfide $\left(\mathrm{FeS}_{2}\right)$, alkylsulphides + thiophenes + arylsulphides, sulphoxides, sulphones, and sulphates [28 - 30].

The peaks for sulphates were weakened from raw coal surface to pyrolysis coal surface while the signal strength of $\mathrm{FeS}$ and $\mathrm{FeS}_{2}$ became stronger for the migration of the sulfate sulfur to the pyrite sulfur occurred when samples were pyrolyzed [25 - 27]. In addition, the area of peaks for alkylsulphides, thiophenes, arylsulphides, sulphoxides, and sulphones became smaller for pyrolysis coal surface compared with that for raw coal surface. This indicated that high amounts of organic sulfur decomposed during the pyrolysis and should be transferred into sulfurcontaining gas/liquid compounds [22, 31, 32]. Thus, the sulfur composition, especially the organic fraction was significantly reduced by the pyrolysis.

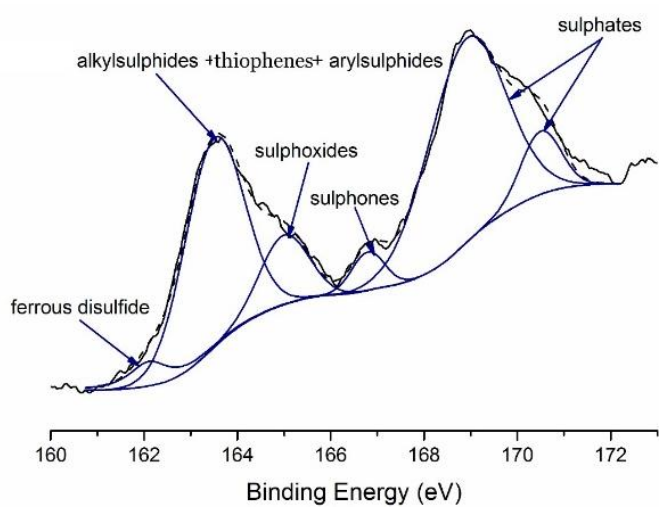

Figure 2 S2p peak fitting for raw coal surface

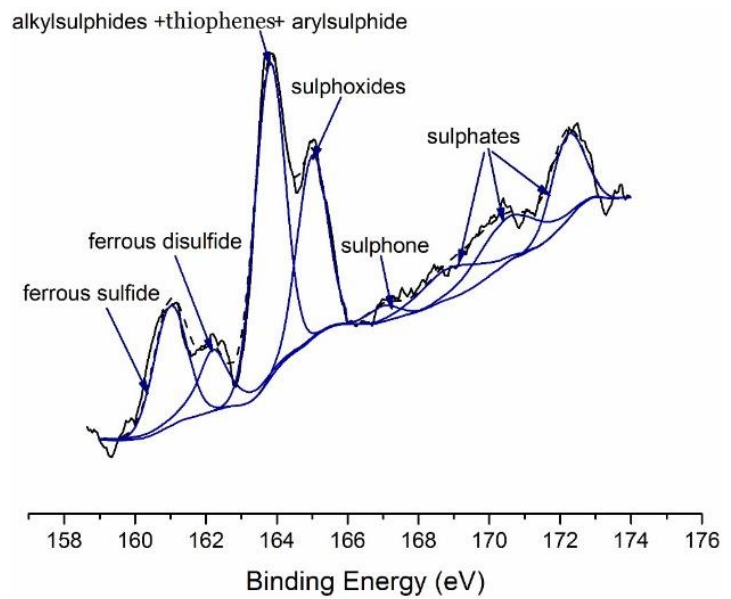

Figure $3 \mathrm{~S} 2 p$ peak fitting for $700^{\circ} \mathrm{C}$ pyrolysis coal char surface 


\subsection{Effect of pyrolysis temperature on coal calorific value}

Figure 4 shows that net calorific value (at constant volume and air dry basis) of coal increased when the heating treatment temperature rose. However, the coal calorific value did not change significantly when the heating treatment temperature raised from 700 to 800 ${ }^{\circ} \mathrm{C}$. Therefore, the heating temperature of $700{ }^{\circ} \mathrm{C}$ proved to be the best temperature again related to the sulfur content changes in Figure 1.

Figure 4 also illustrates that the moisture content decreased with increasing temperature while the ash content increased. The coal char suffered from pyrolysis had lower ability to adsorb the moisture and hence had a low moisture content. Because the decomposition of organic materials from coal forming the gas/liquid compounds, the ash content significantly increased. The calorific value is usually influenced by both the ash content and moisture content. The higher moisture content needs more heating for the evaporation of moisture and hence it reduces the calorific value. For this low rank coal sample, the decrease in moisture content was more important than the increase in ash content with regard to the caloric value. Therefore, the caloric value of low rank coal sample significantly enhanced by the pyrolysis, as well as the coal desulfurization, can be achieved.

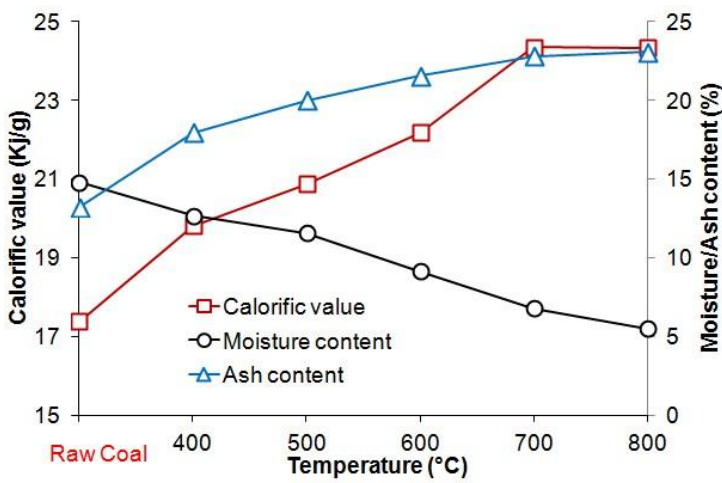

Figure 4 Changes in net calorific value of coal with pyrolysis temperature

\section{Conclusion}

Throughout this paper, the sulfur removal from low rank coal with high organic sulfur via the pyrolysis under low temperature was explored, and meanwhile the influence of pyrolysis treatment on the coal calorific value were investigated as well. The sulfur composition was cut down from $2.32 \%$ to $1.68 \%$ after pyrolysis of $700{ }^{\circ} \mathrm{C}$, while the coal calorific value increased from 17.38 to $24.35 \mathrm{~kJ} / \mathrm{g}$. The optimized performance was acquired when the temperature reached $700{ }^{\circ} \mathrm{C}$. Under this temperature, high amounts of organic sulfur decomposed and was transferred into sulfur-containing gas/liquid. The XPS results showed that the sulphates on coal surface could be transferred into $\mathrm{FeS}$ and $\mathrm{FeS}_{2}$ as well as amounts of organic sulfur in coal surface, such as alkylsulphides, thiophenes, arylsulphides, sulphoxides, and sulphones were decomposed. The low temperature pyrolysis could reduce the sulfur composition of coal, also it promoted the calorific value of pyrolysis-derived char. Therefore, low temperature pyrolysis is suitable for the low rank coal conversion and better utilization.

\section{References}

[1] Amjed, N., Bhatti, I.A., Nazir, A., Iqbal, M. (2017) Microwave-assisted desulfurization of coal by photo-catalytic oxidation treatment. Energy Sources, Part A: Recovery, Utilization, and Environmental Effects 39 (10), 1043-1049.

[2] Baatar, B., Gan-Erdene, T., Myekhlai, M., Otgonbayar, U., Majaa, C., Turmunkh, Y., Javkhlantugs, N. (2017) Desulfurization of coal using the electrochemical technique in neutral and alkaline media. Energy Sources, Part A: Recovery, Utilization, and Environmental Effects 39 (15), 1610-1616.

[3] Cheng, J., Zhou, J., Liu, J., Zhou, Z., Huang, Z., Cao, X., Zhao, X., Cen, K. (2003) Sulfur removal at high temperature during coal combustion in furnaces: a review. Progress in Energy and Combustion Science 29 (5), 381-405.

[4] Iqbal, M., Ghaffar, A., Nazir, A., Yameen, M., Munir, B., Nisar, N., Bokhari, T.H. (2017) Coal desulfurization using gamma and ultraviolet radiation. Energy Sources, Part A: Recovery, Utilization, and Environmental Effects 39 (11), 1109-1115.

[5] Calkins, W.H. (1994) The chemical forms of sulfur in coal: a review. Fuel 73 (4), 475-484.

[6] Wang, H., Song, Q., Yao, Q., CHEN, C.-h. (2008) Experimental study on removal effect of wet flue gas desulfurization system on fine particles from a coal-fired power plant. Proceedings-Chinese Society of electrical engineering 28 (5), 1. 
[7] Demirbaş, A. (2002) Demineralization and desulfurization of coals via column froth flotation and different methods. Energy Conversion and Management 43 (7), 885-895.

[8] Sokolović, J., Stanojlović, R., Marković, Z. (2006) Effect of oxidation on flotation and electro kinetic properties of coal. Journal of Mining and Metallurgy A: Mining, 42 (1), 69-81.

[9] Xia, W., Li, Y., Nguyen, A.V. (2018) Improving coal flotation using the mixture of candle soot and hydrocarbon oil as a novel flotation collector. Journal of Cleaner Production 195, 1183-1189.

[10] Xia, W., Zhou, C., Peng, Y. (2017) Enhancing flotation cleaning of intruded coal dry-ground with heavy oil. Journal of Cleaner Production 161, 591597.

[11] Xia, W., Niu, C., Ren, C. (2017) Enhancement in floatability of sub-bituminous coal by lowtemperature pyrolysis and its potential application in coal cleaning. Journal of Cleaner Production, 168, 1032-1038.

[12] Gürü, M., Sariöz, B., Cakanyildirim, C. (2008) Oxidative desulfurization of tufanbeyli coal by hydrogen peroxide solution. Energy Sources, Part A: Recovery, Utilization, and Environmental Effects 30 (11), 981-987.

[13] Irum, S., Akhtar, J., Sheikh, N., Munir, S. (2017) Oxidative desulfurization of Chakwal coal using potassium permanganate, ferric sulfate, and sodium hypochlorite. Energy Sources, Part A: Recovery, Utilization, and Environmental Effects 39 (4), 426-432.

[14] Mi, J., Ren, J., Wang, J.-C., Bao, W.-R., Xie, K.-C. (2007) Ultrasonic and microwave desulfurization of coal in tetrachloroethylene. Energy Sources, Part A: Recovery, Utilization, and Environmental Effects 29 (14), 1261-1268.

[15] Tang, L., Fan, H., Guo, J., Zeng, W., Tao, X. (2018) Investigation on the mechanism of coal desulfurization by ultrasonic with peroxyacetic acid. Energy Sources, Part A: Recovery, Utilization, and Environmental Effects, 1-11.

[16] Wahab, A., Nawaz, S., Shahzad, K., Akhtar, J., Kanwal, S., Munir, S., Sheikh, N. (2015) Desulfurization and demineralization of lakhra coal by molten caustic leaching. Energy Sources, Part A: Recovery, Utilization, and Environmental Effects 37 (11), 1219-1223.

[17] Lin, D., Qiu, P., Xie, X., Zhao, Y., Chen, G., Zeng, L. (2018) Chemical structure and pyrolysis characteristics of demineralized Zhundong Coal. Energy Sources, Part A: Recovery, Utilization, and Environmental Effects 40 (3), 282-287.

[18] Wang, B., Li, L., Huang, Y., Zhang, J. (2016) Behavior of sulfur and arsenic during co-pyrolysis of Tuanbo-2 coal and sawdust when adding crown ether. Energy Sources, Part A: Recovery, Utilization, and Environmental Effects 38 (6), 882889.

[19] Xu, L. (2003) Effects of organic gaseous additives on desulfurization of coal during pyrolysis. Energy sources 25 (10), 1033-1042.

[20] Xu, L., Ni, J., Yang, J., Li, Y., Liu, Z. (2006) Dynamic behaviors of sulfur evolved in the gas phase from pyrolysis of six Chinese coals. Energy Sources, Part A: Recovery, Utilization, and Environmental Effects 28 (3), 281-293.

[21] Yan, J., Yang, J., Liu, Z. (2005) SH radical: the key intermediate in sulfur transformation during thermal processing of coal. Environmental science \& technology 39 (13), 5043-5051.

[22] Gryglewicz, G.y., Wilk, P., Yperman, J., Franco, D.V., Maes, I.I., Mullens, J., Van Poucke, L.C. (1996) Interaction of the organic matrix with pyrite during pyrolysis of a high-sulfur bituminous coal. Fuel 75 (13), 1499-1504.

[23] Telfer, M., Zhang, D.-k. (2001) The influence of water-soluble and acid-soluble inorganic matter on sulphur transformations during pyrolysis of low-rank coals. Fuel 80 (14), 2085-2098.

[24] Xia, W., Li, Y., He, W., Peng, Y. (2018) Desulfurization of low rank coal co-pyrolysis with reduced iron powder followed by dry magnetic separation. Journal of Cleaner Production, 204, 525-531.

[25] Ibarra, J., Palacios, J., Moliner, R., Bonet, A.J. (1994) Evidence of reciprocal organic matter-pyrite interactions affecting sulfur removal during coal pyrolysis. Fuel 73 (7), 1046-1050.

[26] Mullens, S., Yperman, J., Reggers, G., Carleer, R., Buchanan III, A.C., Britt, P.F., Rutkowski, P., Gryglewicz, G. (2003) A study of the reductive pyrolysis behaviour of sulphur model compounds. Journal of Analytical \& Applied Pyrolysis 70 (2), 469-491.

[27] Yani, S., Zhang, D. (2010) An experimental study of sulphate transformation during pyrolysis of an Australian lignite. Fuel Processing Technology 91 (3), 313-321.

[28] Grzybek, T., Pietrzak, R., Wachowska, H. (2002) 
X-ray photoelectron spectroscopy study of oxidized coals with different sulphur content. Fuel Processing Technology 77, 1-7.

[29] Grzybek, T., Pietrzak, R., Wachowska, H. (2004) The comparison of oxygen and sulfur species formed by coal oxidation with $02 / \mathrm{Na} 2 \mathrm{CO} 3$ or peroxyacetic acid solution. XPS studies. Energy \& fuels 18 (3), 804-809.

[30] Pietrzak, R., Wachowska, H. (2006) The influence of oxidation with $\mathrm{HNO} 3$ on the surface composition of high-sulphur coals: XPS study. Fuel processing technology 87 (11), 1021-1029.

[31] Xia, W. (2018) A novel and effective method for removing organic sulfur from low rank coal. Journal of Cleaner Production 172, 2708-2710.

[32] Xia, W., Niu, C. (2018) Effect of middle-temperature pyrolysis on the surface hydrophobicity of subbituminous coal. Energy Sources, Part A: Recovery, Utilization, and Environmental Effects, 40 (3), 320-326.

\title{
UTICAJ TEMPERATURE PIROLIZE NA STEPEN ODSUMPORAVANJA UGLJA NIŽEG RANGA SA VISOKIM SADRŽAJEM ORGANSKOG SUMPORA
}

\author{
W. Xia ${ }^{1 \#}$, W. He${ }^{1}$, J. Sokolović2 \\ ${ }^{1}$ China University of Mining and Technology, \\ School of Chemical Engineering and Technology, Jiangsu, China \\ 2University in Belgrade, Technical Faculty, Bor, Serbia
}

Primljen: 2. novembar 2020.; Prihvaćen: 30. mart 2021.

\section{Izvod}

Sumpor u uglju utiče ne samo na kvalitet koksa već i zagađuje životnu sredinu prilikom sagorevanja. Postupak odsumporavanja uglja sa visokim sadržajem organskog sumpora predstavlja ključno pitanje u nauci o čišćenje uglja. Kako se piroliza koristi u konverziji uglja niskog ranga za dobijanje gasnih/tečnih proizvoda i drvenog uglja, uticaj odsumporavanja prilikom pirolize uglja niskog ranga sa visokim sadržajem organskog sumpora zahteva dalja istraživanja. U ovom radu je ispitivan stepen odsumporavanja uglja niskog ranga sa visokim sadržajem sumpora, kao i promena kalorijske vrednosti uglja i oblika sumpora tokom pirolize. Za analizu promene regulacije sumpora koji nastaje na površini uglja primenjen je XPS. Rezultati su pokazali da je određena količina FeS nastala prilikom pirolize, a da su velike količine sulfatnog sumpora prešle u piritni sumpor i formirale više FeS2 u poređenju sa rovnim ugljem. Ukupan sadržaj sumpora u uglju je smanjen sa 2,32\% za rovni ugalj na 1,68\% za ugalj dobijen pirolizom na $700^{\circ} \mathrm{C}$ i tada je temperatura pirolize imala mali uticaj na sadržaj sumpora. Ukupna kalorična vrednost (pri konstantnoj zapremini i na suvom vazduhu) povećana je sa 17,38 kJ za rovni ugalj na 24,35 kJ za ugalj dobijen pirolizom na $700^{\circ} \mathrm{C}$. Temperatura pirolize od $700^{\circ} \mathrm{C}$ se može smatrati najboljom temperaturom za ovaj postupak zbog niskog sadržaja sumpora i visoke toplotne vrednosti.

Ključne reči: Odsumporavanje uglja; Piroliza; XPS; Kalorična vrednost; Sadržaj sumpora. 